\title{
Karyological study of Amphisbaena ridleyi (Squamata, Amphisbaenidae), an endemic species of the Archipelago of Fernando de Noronha, Pernambuco, Brazil
}

\author{
Marcia Maria Laguna ${ }^{1}$, Renata Cecília Amaro $^{2}$, Tamí Mott ${ }^{3}$, Yatiyo Yonenaga-Yassuda ${ }^{1}$ \\ and Miguel Trefaut Rodrigues ${ }^{2}$ \\ ${ }^{I}$ Departamento de Genética e Biologia Evolutiva, Instituto de Biociências, Universidade de São Paulo, \\ São Paulo, SP, Brazil. \\ ${ }^{2}$ Departamento de Zoologia, Instituto de Biociências, Universidade de São Paulo, São Paulo, SP, Brazil. \\ ${ }^{3}$ Instituto de Biociências, Programa de Pós Graduação em Ecologia e Conservação da Biodiversidade, \\ Universidade Federal do Mato Grosso, Cuiabá, MT, Brazil.
}

\begin{abstract}
The karyotype of Amphisbaena ridleyi, an endemic species of the archipelago of Fernando de Noronha, in State of Pernambuco, Brazil, is described after conventional staining, Ag-NOR impregnation and fluorescence in situ hybridization (FISH) with a telomeric probe. The diploid number is 46 , with nine pairs of macrochromosomes (three metacentrics, four subtelocentrics and two acrocentrics) and 14 pairs of microchromosomes. The Ag-NOR is located in the telomeric region of the long arm of metacentric chromosome 2 and FISH revealed signals only in the telomeric region of all chromosomes. Further cytogenetic data on other amphisbaenians as well as a robust phylogenetic hypothesis of this clade is needed in order to understand the evolutionary changes on amphisbaenian karyotypes.
\end{abstract}

Key words: Amphisbaena ridleyi, karyotype, Fernando de Noronha, Ag-NOR, FISH with telomeric probes.

Received: February 9, 2009; Accepted: August 24, 2009.

Amphisbaenians, or worm lizards, are a monophyletic group of squamates mostly distributed nowadays in Africa and South America (Gans, 1990, 2005; Kearney, 2003; Kearney and Stuart, 2004; Macey et al., 2004). Due to their fossorial lifestyle and the consequent challenge for collecting them, the group is probably the least-studied group of squamates and many aspects of its biology remain enigmatic.

Although a phylogenetic hypothesis based on morphological and molecular characters for the group was only recently proposed (Kearney, 2003; Kearney and Stuart, 2004; Macey et al., 2004; Vidal et al., 2008), karyological studies on amphisbaenians date back from the 1960's. The karyotypes of 35 out of the 190 recognized amphisbaenian species have been described, mostly including only data on diploid number and chromosomal morphology (Table 1). Amphisbaenian karyotypes present variable diploid number and morphology with distinctive macro and microchromosomes. Diploid numbers range from $2 \mathrm{n}=26$ in Amphisbaena dubia and Anops kingi to 2n $=50$ in Amphis-

Send correspondence to Marcia Maria Laguna. Departamento de Genética e Biologia Evolutiva, Instituto de Biociências, Universidade de São Paulo, 05508-090 São Paulo, SP, Brazil. E-mail: laguna.mm@gmail.com. baena leberi and A. innocens (Huang and Gans, 1971; Beçak et al., 1971a, 1972; Cole and Gans, 1987). This variability is in strong contrast with the conserved karyotype composed by 36 chromosomes $(12 \mathrm{M}+24 \mathrm{~m})$ found in many groups of lizards and considered as the primitive karyotype within Squamata (Olmo, 1986). Except for the study of Hernando (2005) describing the localization of nucleolar organizer regions (NORs) in four South American species, all chromosomal studies in amphisbaenians only presented conventional staining data.

Herein we describe the chromosome constitution of Amphisbaena ridleyi, a species endemic to the oceanic archipelago of Fernando de Noronha, Pernambuco, Brazil. Although this species resembles some African members in some external attributes, molecular data indicate that it is closely related to the South American genus Amphisbaena (Gans, 1963; T. Mott, unpublished data). Karyotypic data presented here support the idea that amphisbaenian karyotypes are highly variable and might assemble phylogenetically informative characters. This information allied to phylogenetic hypotheses of amphisbaenian relationships would help to understand the chromosome evolution in this interesting group of fossorial squamates.

Three individuals of Amphisbaena ridleyi were collected by two of us (TM, MTR; IBAMA permit number 
Table 1 - Chromosomal revision of amphisbaenians, with descriptions of diploid number (2n), fundamental number (FN), number and morphology of macrochromosomes, number of microchromosomes, references and occurrence of species.

\begin{tabular}{|c|c|c|c|c|c|c|}
\hline Species & $2 n$ & Macro (n. biarmed, n. uniarmed) & micro & FN & Reference $^{1}$ & Occurrence \\
\hline \multicolumn{7}{|l|}{ Amphisbaenidae } \\
\hline Amphisbaena alba & 38 & $22(14,8)$ & 16 & 64 & $4,5,6,7$ & South America \\
\hline Amphisbaena angustifrons & 30 & $12(12,0)$ & 18 & 42 & 2 & South America \\
\hline Amphisbaena caeca & 36 & $12(12,0)$ & 24 & 48 & 2 & Central America \\
\hline Amphisbaena camura & 44 & $24(4,20)$ & 20 & $48-50^{2}$ & 2 & South America \\
\hline Amphisbaena darwini & 30 & $12(12,0)$ & 18 & 46 & 2 & South America \\
\hline Amphisbaena dubia & $\begin{array}{l}25, \\
26, \\
27, \\
28\end{array}$ & $\begin{array}{l}15(12,3), \\
14(12,2), \\
13(12,1), \\
12(12,0)\end{array}$ & $\begin{array}{l}10, \\
12, \\
14, \\
16\end{array}$ & - & 3,6 & South America \\
\hline Amphisbaena fenestrata & 36 & $12(12,0)$ & 24 & $52-56^{2}$ & 5 & Central America \\
\hline Amphisbaena fuliginosa & 48 & $22(6,16)$ & 26 & 60 & 5 & South America \\
\hline Amphisbaena heterozonota & $\begin{array}{l}30 \\
30\end{array}$ & $\begin{array}{l}12(12,0) \\
12(12,0)\end{array}$ & $\begin{array}{l}18 \\
18\end{array}$ & $\begin{array}{l}46 \\
60\end{array}$ & $\begin{array}{c}2 \\
12,13\end{array}$ & South America \\
\hline Amphisbaena hiata & 30 & $12(12,0)$ & 18 & 60 & 12,13 & South America \\
\hline Amphisbaena innocens & 50 & $22(8,14)$ & 28 & - & 5 & Central America \\
\hline Amphisbaena leberi & 50 & $22(8,14)$ & 28 & - & 11 & Central America \\
\hline Amphisbaena manni & 36 & $12(12,0)$ & 24 & - & 5 & Central America \\
\hline Amphisbaena mertensi & 40 & $18(6,12)$ & 22 & - & 12 & South America \\
\hline Amphisbaena ridleyi & 48 & $18(14,4)$ & 28 & - & Present work & South America \\
\hline Amphisbaena trachura & 30 & $12(12,0)$ & 18 & 46 & 2 & South America \\
\hline Amphisbaena vermicularis & 44 & $22(2,20)$ & 22 & 46 & 7,8 & South America \\
\hline Amphisbaena xera & 36 & $12(12,0)$ & 24 & 48 & 2 & Central America \\
\hline Anops kingi & 26 & $12(12,0)$ & 14 & - & 5 & South America \\
\hline Chirindia langi & $\begin{array}{l}30 \\
34\end{array}$ & $\begin{array}{l}12(12,0) \\
12(12,0)\end{array}$ & $\begin{array}{l}18 \\
22\end{array}$ & - & 5 & Africa \\
\hline Chirindia sp & $\begin{array}{l}30 \\
32\end{array}$ & $\begin{array}{l}12(12,0) \\
12(12,0)\end{array}$ & $\begin{array}{l}18 \\
20\end{array}$ & $\begin{array}{c}46-50^{2} \\
-\end{array}$ & 5 & Africa \\
\hline Cynisca leucura & $\begin{array}{l}30 \\
32\end{array}$ & $\begin{array}{l}12(12,0) \\
12(12,0)\end{array}$ & $\begin{array}{l}18 \\
20\end{array}$ & & 5 & Africa \\
\hline Geocalamus acutus & 38 & $14(10,4)$ & 24 & - & 5 & Africa \\
\hline Leptosternon microcephalum & $\begin{array}{l}34 \\
32 \\
34\end{array}$ & $\begin{array}{l}12(12,0) \\
12(12,0) \\
12(2,22)\end{array}$ & $\begin{array}{l}22 \\
20 \\
22\end{array}$ & $\begin{array}{l}48 \\
44 \\
46\end{array}$ & $\begin{array}{c}4,6 \\
2 \\
2,12,13\end{array}$ & South America \\
\hline Mesobaena huebneri & 46 & $24(2,22)$ & 22 & - & 10 & South America \\
\hline Monopeltis capensis & 34 & $12(12,0)$ & 22 & 62 & 5 & Africa \\
\hline Zygaspis quadrifrons & $\begin{array}{l}36 \\
36\end{array}$ & $\begin{array}{l}12(12,0) \\
12(12,0)\end{array}$ & $\begin{array}{l}24 \\
24\end{array}$ & $\begin{array}{l}50 \\
72\end{array}$ & $\begin{array}{l}2 \\
5\end{array}$ & Africa \\
\hline Zygaspis violacea & 36 & $12(12,0)$ & 24 & - & 5 & Africa \\
\hline \multicolumn{7}{|l|}{ Bipedidae } \\
\hline Bipes biporus & $\begin{array}{l}40 \\
42\end{array}$ & $\begin{array}{l}20(20,0) \\
20(20,0)\end{array}$ & $\begin{array}{l}20 \\
22\end{array}$ & $\begin{array}{l}60 \\
66\end{array}$ & $\begin{array}{c}2 \\
5,9,11\end{array}$ & North America \\
\hline Bipes canaliculatus & $\begin{array}{l}46 \\
46\end{array}$ & $\begin{array}{l}22(16,6) \\
22(20,2)\end{array}$ & $\begin{array}{l}24 \\
24\end{array}$ & $\begin{array}{l}- \\
-\end{array}$ & $\begin{array}{c}9 \\
11\end{array}$ & North America \\
\hline Bipes tridactylus & 46 & $22(18,4 ?)$ & 24 & - & 11 & North America \\
\hline \multicolumn{7}{|l|}{ Blanidae } \\
\hline Blanus cinereus & 32 & $12(12,0)$ & 20 & 44 & 2 & Europe \\
\hline Blanus strauchi & 32 & $12(12,0)$ & 20 & 44 & 2 & Europe \\
\hline \multicolumn{7}{|l|}{ Rhineuridae } \\
\hline Rhineura floridana & $\begin{array}{l}46 \\
44 \\
\end{array}$ & $\begin{array}{l}20(2,18) \\
24(16,8)\end{array}$ & $\begin{array}{l}26 \\
20 \\
\end{array}$ & $\begin{array}{c}- \\
54-56^{2} \\
\end{array}$ & $\begin{array}{l}1 \\
2 \\
\end{array}$ & North America \\
\hline \multicolumn{7}{|l|}{ Trogonophiidae } \\
\hline Diplometopon zarudnyi & 36 & $12(12,0)$ & 24 & 52 & 2,10 & Africa \\
\hline Trogonophis elegans & 36 & $12(12,0)$ & 24 & 48 & 2 & Africa \\
\hline
\end{tabular}

': 1. Matthey (1933); 2. Huang et al. (1967); 3. Beçak et al. (1971a); 4. Beçak et al. (1971b); 5. Huang and Gans (1971); 6. Beçak et al. (1972); 7. Beçak et al (1973a); 8. Beçak et al. (1973b); 9. Macgregor and Klosterman (1979); 10. Branch (1980); 11. Cole and Gans (1987); 12. Hernando (2005); 13. Hernando and Alvarez (2005).

${ }^{2}$ : The variation of FN, according to the authors, is due to the difficulty in determining microchromosome morphology. 
02010.000240/2007-03), one male (MZUSP 98333) and one female (MZUSP 98335) from the Ilha Rata ( $3^{\circ} 48^{\prime} 47.6^{\prime \prime}$ S, 32 $23^{\prime} 21.5^{\prime \prime} \mathrm{W}$ ) and one female (MZUSP 98338) from the Ilha Fernando de Noronha ( $3^{\circ} 51^{\prime} 21.2^{\prime \prime}$ S, 32 $26^{\circ} 31.5^{\prime \prime}$ W), both in the archipelago of Fernando de Noronha, Pernambuco, Brazil. The animals were brought alive to the Laboratório de Citogenética de Vertebrados, Departamento de Genética e Biologia Evolutiva, Instituto de Biociências, Universidade de São Paulo, Brazil and after chromosomal preparations were made, the specimens were deposited in the herpetological collection of Museu de Zoologia, Universidade de São Paulo.

The animals were injected with colchicine, according to routine techniques (Kasahara et al., 1987), and chromosomal spreads were obtained from the liver. The diploid number and the localization of Ag-NORs were established after conventional staining and silver staining impregnation (Howell and Black, 1980), respectively. Fluorescence in situ hybridization (FISH) was performed using the Telomere PNA FISH Kit/Cy3 (DAKO, code No. K 5326), according to manufacturer's instructions. FISH signals were visualized using a Zeiss Axiophot microscope equipped with a FITC filter using the softwares Ikaros \& Isis v. 5.0 (Zeiss).

Amphisbaena ridleyi from the Ilhas Rata and Fernando de Noronha had similar karyotype numbers composed by 46 chromosomes, with 9 pairs of macrochromosomes and 14 pairs of microchromosomes $(2 \mathrm{n}=46,18 \mathrm{M}+28 \mathrm{~m})$ (Figure 1). The macrochromosomes are three metacentric pairs (1,2 and 4), two acrocentric pairs (8 and 9) and four subtelocentric pairs (3, 5, 6 and 7), although in some metaphases the short arms of some of these chromosomes was extremely reduced. There was not enough resolution to

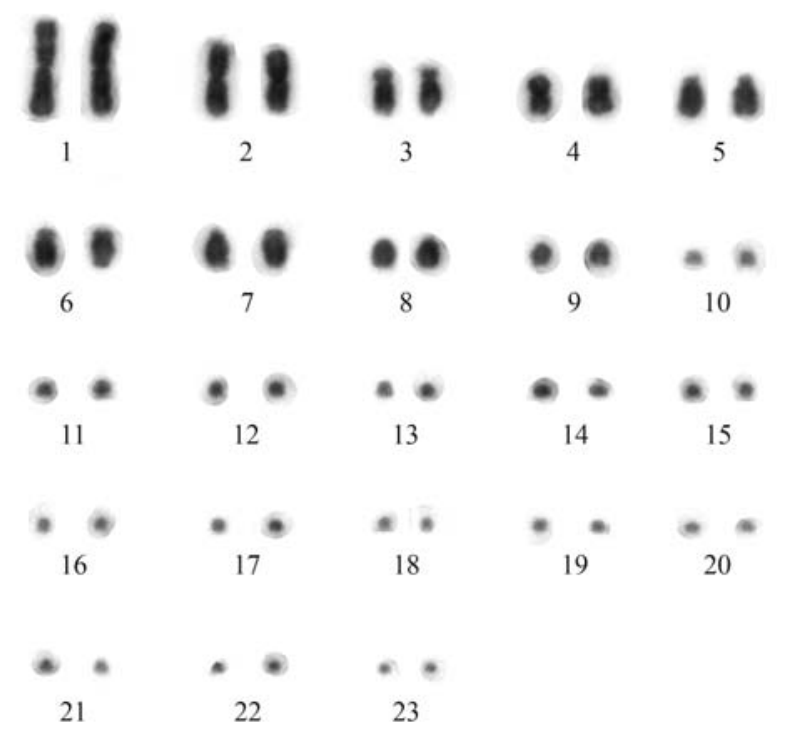

Figure 1 - Conventionally stained karyotype of Amphisbaena ridleyi, female, $2 \mathrm{n}=46(18 \mathrm{M}+28 \mathrm{~m})$, from Fernando de Noronha, Pernambuco, Brazil. morphologically identify the 14 pairs of microchromosomes. No secondary constrictions or heteromorphic sex chromosomes were observed.

The karyotype described for $A$. ridleyi $(2 \mathrm{n}=46,18 \mathrm{M}$ $+28 \mathrm{~m}$ ) is unique among its congeners (Huang et al., 1967; Huang and Gans, 1971; Beçak et al., 1972, 1973a; Cole and Gans, 1987; Hernando, 2005). Furthermore, the comparison of the karyotype of $A$. ridleyi with those of other amphisbaenian genera with the same diploid number, such as Bipes canaliculatus, Bipes tridactylus $(22 \mathrm{M}+24 \mathrm{~m})$, Mesobaena huebneri $(24 \mathrm{M}+22 \mathrm{~m})$ and Rhineura floridana $(26 \mathrm{M}+20 \mathrm{~m})$, revealed that the number of macro and microchromosomes and the number of biarmed chromosomes were very distinct among different genera, (Table 1) (Matthey, 1933; Huang et al., 1967; Macgregor and Klosterman, 1979; Cole and Gans, 1987).

Despite the fact that only $20 \%$ of amphisbaenian species have had their karyotypes studied, a great variability of diploid numbers has been observed. There are 77 described species of Amphisbaena (Gans, 2005; Mott et al. 2008, 2009) from which 18 had their karyotypes described, including A. ridleyi from the present study. This is the genus that exhibits the higher variability in chromosome number and morphology, including all the range of variation found in amphisbaenians, such as $2 \mathrm{n}=26(14 \mathrm{M}+12 \mathrm{~m})$ in males and $2 \mathrm{n}=25,26,27$ and 28 in females of A. dubia; $2 \mathrm{n}=30$ $(12 \mathrm{M}+18 \mathrm{~m})$ in $A$. angustifrons, $A$. darwini, A. heterozonata, A. hiata, A. trachura; $2 \mathrm{n}=36(12 \mathrm{M}+24 \mathrm{~m})$ in $A$. caeca, A. fenestrata, A. manni, A. xera $; 2 \mathrm{n}=38(22 \mathrm{M}+$ $16 \mathrm{~m})$ in A. alba; $2 \mathrm{n}=40(18 \mathrm{M}+22 \mathrm{~m})$ in A. mertensi; $2 \mathrm{n}=44$ in $A$. camura $(24 \mathrm{M}+20 \mathrm{~m})$ and $A$. vermicularis $(22 \mathrm{M}+22 \mathrm{~m}) ; 2 \mathrm{n}=48(22 \mathrm{M}+26 \mathrm{~m})$ in A. fuliginosa and $2 \mathrm{n}=50(22 \mathrm{M}+28 \mathrm{~m})$ in A. leberi and A. innocens (Table 1). Probably fusion/fission rearrangements occurred in the karyotypic diversification of amphisbaenians (Cole and Gans, 1987; Hernando, 2005), but the number of taxa studied and the absence of differential staining do not allow more detailed hypotheses on the karyotypic evolution of this group.

Some karyotypes reported in the literature do not allow to determine the fundamental number due to the difficulty of identifying the morphology of the microchromosomes. The species A. dubia showed an intraindividual variation of the diploid number, involving macro-and microchromosomes, and the authors suggested that this would be due to fusions/fissions of microchromosomes (Beçak et al. 1971a, 1972). However, the polymorphism detected in A. dubia should be viewed with reservations due to the low quality of the chromosome preparations.

The Ag-NORs of all specimens of A. ridleyi were located in the telomeric region of the long arm of the metacentric pair 2 (Figure 2) in 17 metaphases on specimens from Ilha Rata and in 13 metaphases on the specimen from Fernando de Noronha, differing from all four South American amphisbaenian species previously studied (Hernando, 


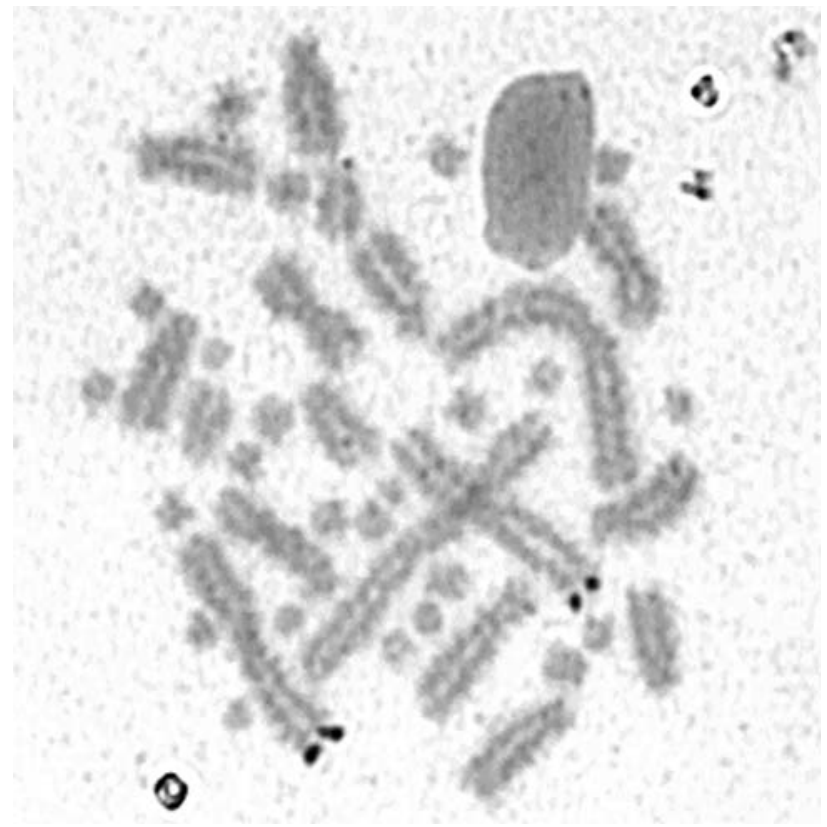

Figure 2 - Incomplete metaphase after silver staining showing the AgNORs on the telomeric region of chromosome 2 of Amphisbaena ridleyi from Fernando de Noronha (Pernambuco, Brazil).

2005). In Leposternum microcephalum $(2 \mathrm{n}=34,12 \mathrm{M}+$ $22 \mathrm{~m}), \mathrm{Ag}$-NORs were detected in the telomeric region of the long arm of pair 3; in A. hiata $(2 \mathrm{n}=30,12 \mathrm{M}+18 \mathrm{~m})$ it was located in the subterminal portion of the short arm of pair 4; in A. mertensi $(2 \mathrm{n}=40,18 \mathrm{M}+22 \mathrm{~m})$ a medium acrocentric macrochromosome was the Ag-NOR-bearing pair, and in A. heterozonata $(2 \mathrm{n}=30,12 \mathrm{M}+18 \mathrm{~m}), \mathrm{Ag}$ NORs were found either in pair 2 or in pairs 1,3 and 4 (Hernando, 2005).

Fluorescence in situ hybridization using the $(\mathrm{TTAGGG})_{\mathrm{n}}$ sequence detected signals on the telomeric regions of all chromosomes of $A$. ridley (Figure 3 ). Some of the signals were tiny and sometimes it was difficult to visualize them in the photographs. Despite the small number of studies using fluorescence in situ hybridization in Squamata, different patterns of distribution of telomeric sequences were observed. In Leposoma scincoides (Gymnophthalmidae), Polychrus marmoratus (Polychrotidade) and Phrynosoma cornutum (Phrynosomatidae) only telomeric signals were detected, while the chromosomes of Cnemidophorus sexlineatus, C. guturalis (Teiidae), Scelophorus olivaceus, Cophosaurus texanus (Phrynosomatidae), Gonatodes taniae (Gekkonidae), Leposoma guianense, Leposoma osvaldoi (Gymnophthalmidae) and Polychrus acutirostris (Polychrotidade) presented additional interstitial telomeric sites (Meyne et al., 1989, 1990; Schmid et al., 1994; Pellegrino et al., 1999; Bertolotto et al., 2001). The exclusive telomeric pattern observed in A. ridleyi is the first report of FISH for amphisbaenids.

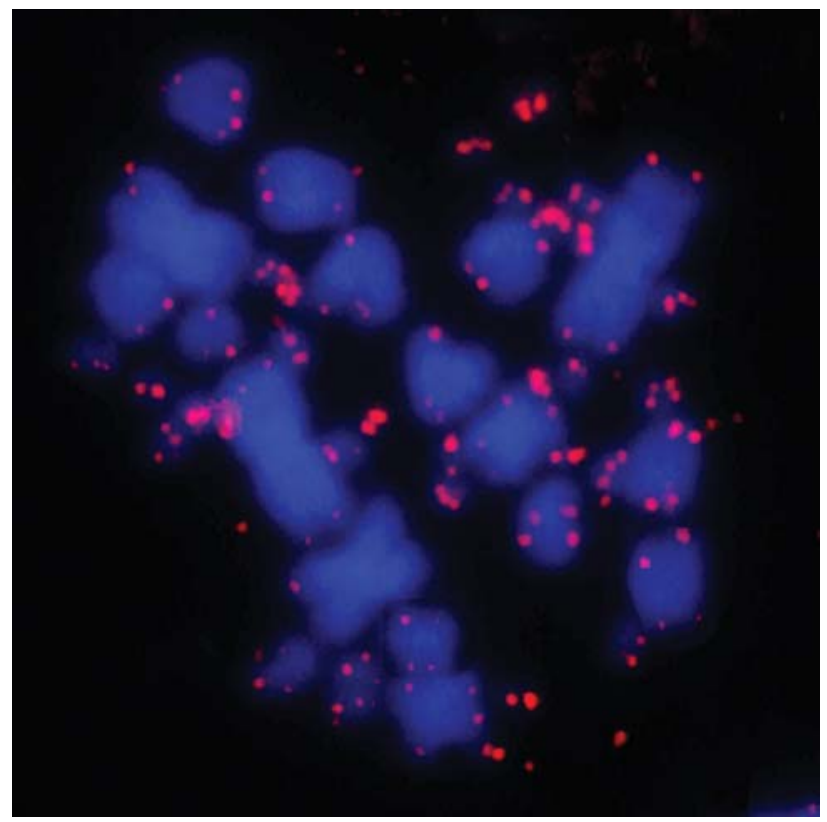

Figure 3 - Distribution of the (TTAGGG) $)_{\mathrm{n}}$ sequence in chromosomes of Amphisbaena ridleyi, from Fernando de Noronha (Pernambuco, Brazil).

The New World amphisbaenids form a monophyletic group within the paraphyletic radiation of African amphisbaenids (Kearney and Stuart, 2004; Vidal et al., 2008). African members of Amphisbaenidae show a lower range of variation in diploid number, like Cynisca leucura $(2 \mathrm{n}=30)$ and Geocalamus acutus ( $2 n=38)$ (Huang and Gans, 1971), when compared to South American congeners. Nevertheless, a more complete taxonomic sampling, including cytogenetic data with differential staining analyses, is needed in order to obtain a better picture of karyotype evolution in amphisbaenids. Despite the scarce information about Ag-NORs location on amphisbaenian karyotypes, the preliminary data available suggest that this marker is phylogenetically informative. We strongly recommend that further studies on amphisbaenian karyotypes include this information.

\section{Acknowledgments}

We thank Fundação de Amparo à Pesquisa do Estado de São Paulo (FAPESP), CNPq, CAPES for the financial support and IBAMA for collection permits.

\section{References}

Beçak ML, Beçak W and Denaro L (1971a) Polimorfismo cromossômico intraindividual em Amphisbaena dubia (Sauria). Cienc Cult 23:123.

Beçak ML, Beçak W and Denaro L (1971b) Cariologia comparada em oito espécies de lacertílios. Cienc Cult 23:124.

Beçak ML, Beçak W and Denaro L (1972) Chromosome polymorphism, geographical variation and karyotypes in Sauria. Caryologia 25:313-326. 
Beçak ML, Beçak W and Napoleone LF (1973a) Amphisbaena vermicularis. In: Benirschke $\mathrm{K}$ and Hsu TC (eds) Chromosome Atlas: Fish, Amphibians, Reptiles and Birds, v. 2. Springer-Verlag, Berlin and Heidelberg, New York, pp R-25.

Beçak ML, Beçak W, Napoleone LF and Reis L (1973b) Contribuição ao estudo cariotípico e variação de DNA em lacertílios. Cienc Cult 25:219.

Bertolotto CEV, Rodrigues MT and Yonenaga-Yassuda Y (2001) Banding patterns, multiple sex chromosome system and localization of telomeric (TTAGGG)n sequences by FISH on two species of Polychrus (Squamata, Polychrotidae). Caryologia 54:217-226.

Branch WR (1980) Chromosome morphology of some reptiles from Oman and adjacent territories. J Oman Stud Spec Rep 2:333-345.

Cole CJ and Gans C (1987) Chromosomes of Bipes, Mesobaena, and other amphisbaenians (Reptilia), with comments on their evolution. Am Mus Nov 2869:1-9.

Gans C (1963) Redescription of Amphisbaena ridleyi Boulenger. Copeia 1963:102-107.

Gans C (1990) Patterns in amphisbaenian biogeography. A preliminary analysis. In: Peters G and Hutterer R (eds) Vertebrates in the Tropics. Alexander Koenig Zoological Research Institute and Zoological Museum, Bonn, pp 133-143.

Gans C (2005) Checklist and bibliography of the amphisbaenia of the world. Bull Am Mus Nat Hist 289:130.

Hernando A (2005) Cytogenetic study of Leposternon and Amphisbaena (Amphisbaenia, Squamata). Caryologia 58:178182.

Hernando A and Alvarez B (2005) Estudios cromosómicos en saurios y anfisbénidos del litoral fluvial argentino y área de influencia. Estado del conocimiento. INSUGEO Miscelánea 14:427-440.

Howell WM and Black DA (1980) Controlled silver staining of nucleolus organizer regions with a protective colloidal developer: A 1-step method. Experientia 36:1014-1015.

Huang CC and Gans C (1971) The chromosomes of 14 species of amphisbaenians (Amphisbaenia, Reptilia). Cytogenetics 10:10-22.

Huang CC, Clark HF and Gans C (1967) Karyological studies on fifteen forms of amphisbaenians (Amphisbaenia, Reptilia). Chromosoma 22:1-15.

Kasahara S, Yonenaga-Yassuda Y and Rodrigues MT (1987) Geographical karyotypic variations and chromosome banding patterns in Tropidurus hispidus (Sauria, Squamata) from Brazil. Caryologia 40:3-57.
Kearney M (2003) Systematics of the Amphisbaenia (Lepidosauria, Squamata) based on morphological evidence from recent and fossil forms. Herp Monogr 17:1-74.

Kearney M and Stuart L (2004) Repeated evolution of limblessness and digging heads in worm lizards revealed by DNA from old bones. Proc R Soc B 271:1677-1683.

Macey JR, Papenfuss TJ, Kuel JV, Fourcade HM and Boore JL (2004) Phylogenetic relationships among amphisbaenian reptiles based on complete mitochondrial genome sequences. Mol Phylogenet Evol 33:2-31.

Macgregor H and Klosterman L (1979) Observations on the cytology of Bipes (Amphisbaenia) with special reference to its lampbrush chromosomes. Chromosoma 72:67-87.

Matthey R (1933): Nouvelle contribution a l'etude des chromosomes chez les Sauriens. Rev Suisse Zool 40:281-316.

Meyne J, Ratliff RL and Moyzis RK (1989) Conservation of the human telomere sequence (TTAGGG) $)_{\mathrm{n}}$ among vertebrates. Proc Natl Acad Sci USA 86:7049-7053.

Meyne J, Baker RJ, Hobart HH, Hsu TC, Ryder OA, Ward OA, Wiley JE, Wurster-Hill DH, Yates TL and Moyzis RK (1990) Distribution of non-telomeric sites of the (TTAGGG) $)_{\mathrm{n}}$ telomeric sequence in vertebrate chromosomes. Chromosoma 99:3-10.

Mott T, Rodrigues MT, Freitas MA and Silva TFS (2008) New species of Amphisbaena with a nonautotomic and dorsally tuberculate blunt tail from state of Bahia, Brazil (Squamata, Amphisbaenidae). J Herpetol 42:172-175.

Mott T, Rodrigues MT and Santos EM (2009) A new Amphisbae$n a$ with chevron-shaped anterior body annuli from state of Pernambuco: Brazil (Squamata, Amphisbaenidae). Zootaxa 2165:52-58.

Olmo E (1986) Animal Cytogenetics. Chordata 3. Reptilia. Gebrüder Borntraeger, Berlin, 99 pp.

Pellegrino KCM, Rodrigues MT and Yonenaga-Yassuda Y (1999) Chromosomal evolution in Brazilian lizards of genus Leposoma (Squamata, Gymnophthalmidae) from Amazon and Atlantic rain forest: Banding patterns and FISH of telomeric sequences. Hereditas 131:15-21.

Schmid M, Feichtinger W, Nanda I, Schakowski R, Garcia RV, Puppo JM and Badillo AF (1994) An extraordinary low diploid chromosome number in the reptile Gonatodes taniae (Squamata, Gekkonidae). J Hered 85:255-260.

Vidal N, Azvolinsky A, Cruaud C and Hedges SB (2008) Origin of tropical American burrowing reptiles by transatlantic rafting. Biol Lett 4:115-118.

Associate Editor: Fausto Foresti

License information: This is an open-access article distributed under the terms of the Creative Commons Attribution License, which permits unrestricted use, distribution, and reproduction in any medium, provided the original work is properly cited. 